\title{
Company stakeholders: their position under the new framework
}

\author{
by Lilian Miles
}

The author clarifies the position of stakeholders under the current law before considering the recognition accorded to them by the Company Law Review and the recent White Paper, Modernising Company Law.

I n July 2001, the Company Law Review completed its consultation process to reform the whole structure of company law in the UK (Final Report, July 2001). Following the completion of the review process, the government released a White Paper (July 16, 2002), and invited comments by November 29, 2002. Amongst the many issues the Review tackled was the duties of directors, a subject so important in the quest to ensure good governance within companies. The Review recommended (in the Final Report, 3.5-3.11) that the duties of directors as currently laid down under the common law should be codified in statute. In doing so, the Review effectively followed the recommendations of an earlier Law Commission Report into directors' duties (Company directors: Regulating conflicts of interest and formulating a statement of duties, 1999). A statutory statement would give directors a clear statement of what their duties are, and so bring the law into line with modern business practice and accepted standards of behaviour.

The Government agreed with Review's proposal (White Paper, Modernising company law, Cm 5553, July 2002, Vol 1, Pt 2, 3.2-3.7), and adopted the draft statutory statement of directors' duties drawn up by the Review. It intends to consult further on a revised draft in due course (White Paper, Vol 1, Pt 2, 3.7). It should be noted however that the government did not favour an inclusion of duties to creditors in the statutory statement (White Paper, Vol 1, Pt 2, 3.10). One of the duties of directors, under the new framework, will be:

"...to act in the way he decides, in good faith, would be
most likely to promote the success of the company for the
benefit of its members as a whole, and in deciding what
would be most likely to promote that success, take account in
good faith of all the material factors that it is practicable in
the circumstances for him to identify..." the position of company stakeholders under the new company law framework. It will first clarify their position under the current law and then question the appropriateness of the recognition which both the Review and the government have, under the new framework, accorded to them.

\section{POSITION OF STAKEHOLDERS UNDER THE CURRENT LAW}

What rights do stakeholders currently have under company law, and do directors have a specific duty to take their interests into account? The answer is no. Despite shifts in public opinion on this matter recently (see, for example, the recent public outcry over Railtrack concerning the high profits awarded to shareholders at the expense of poor service to consumers) the current position is effectively that the primary duty of directors is only to the body of shareholders as a whole. Whether or not directors should owe a duty directly to stakeholders has been hotly debated for some time. Indeed company law academics hold diverse views insofar as the principle of shareholder-primacy is concerned and many have argued that company directors have a wider obligation beyond that of profit maximization (see for example Dodd, E M, "For whom are corporate managers trustees?" (1932) 45 Harvard Law Review 1145; Berle A A, 'For whom corporate managers are trustees', (19.32) 45 Harvard Law Review 1365; Lord Wedderburn of Charlton, 'The social responsibility of companies', (1985) 15 MULR 4; Stone, C D 'Corporate social responsibility; what it might mean if it were really to matter' (1986) 71 Iowa Law Review 557).

Official recognition of the interests of company stakeholders in the UK has on the whole, been lukewarm. This is not to say that the government has been oblivious to the needs or interests of stakeholders. On the contrary, ministers have from time to time adopted a moral tone and issued challenges to the corporate community to be 
more ethical and sensitive to the needs of stakeholders in the management of their companies. In October 2001, the Minister for Corporate Social Responsibility, Douglas Alexander MP, said:

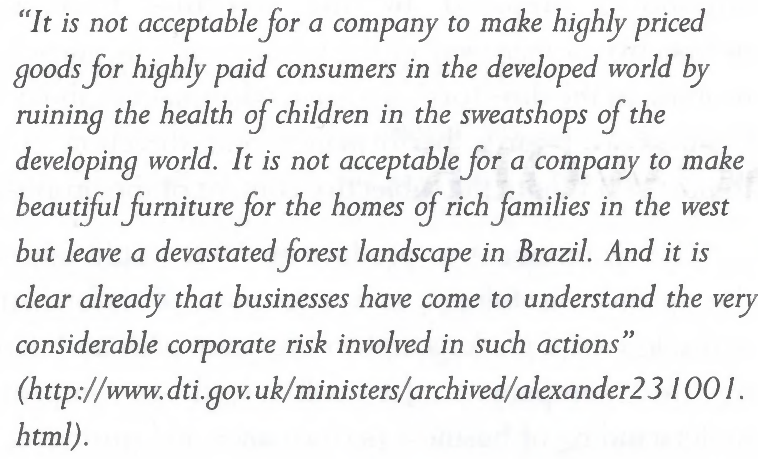

However, few in positions of authority have been enthusiastic in advocating an extension of the duties of directors to persons beyond the body of shareholders. In June 2000, the then Secretary of State for Industry, Stephen Byers MP (in his speech at the TUC/IPPR Seminar on Corporate Governance) recognised that decisions taken by companies affected customers, creditors, the environment and the wider community, and not just the company alone. He rightly pointed out that companies needed to be flexible so that they may consider the wider interests of the company alongside those of their investors, and not merely focus on short term profits. However, he did not think that this justified the law imposing on directors a specific duty to take these wider interests into account. He stressed that it would be difficult for directors to take into account all interests if such a duty were imposed, as there will always be conflicts of interests which it may be difficult, if not impossible to resolve (http://www.dti.gov.uk/ministers/archived/byers070600.ht $\mathrm{ml})$.

In examining the same issue, the Hampel Committee appeared equally ambivalent:

"... to redefine the directors' responsibilities in terms of the stakeholders would mean identifying all the various stakeholder groups; and deciding the nature and extent of the directors' responsibility to each. The result would be that the directors were not effectively accountable to anyone since there would be no clear yardstick for judging their performance..." (see Proctor G and Miles L, Corporate governance, Cavendish, 2002 at p189; "Duty, accountability and the Company Law Review”, (1999) 20 Co Law 233-35).

There is thus no specific duty on directors to take stakeholder interests into account. There is nothing however, preventing them from doing so. In real terms, the function of directors is profit maximisation for their shareholders. There was much debate during the Review's consultation process as to whether company law should adopt a "pluralist approach" to directors' duties (a company should serve a wider range of interests not subordinate to that of shareholders, but which are valid in their own right). The Review rejected this, preferring instead an "enlightened shareholder value" approach (that the primary role of directors should be to promote the success of the company for the benefit of its shareholders as a whole, but that they should also recognise, as the circumstances require, the company's need to foster relationships with other stakeholders, its need to maintain its business reputation and its need to consider the impact of its operations on the community and the environment) (Final Report, 3.8). The Government White Paper endorsed this approach (Vol $1 \mathrm{Pt}$ 2, 3.3, 3.6, Draft statement of directors' duties, Sched 2, Vol 2, Principle 2).

What of the attitude of companies themselves? Are they on the whole, keen to embrace the interests of stakeholders? In 2000, the Prime Minister, Tony Blair MP, urged all large UK-listed companies to publish an environmental report by the end of 2001. In a speech to the CBI in October 2000 he said: "I am issuing a challenge today, to all of the top 350 companies to be publishing annual environment reports by the end of 2001 ."

A survey conducted by corporate social responsibility consultants Environmental Context and Salter Baxter (2000/1) however, showed that the UK's top companies had consistently rejected the government's calls to disclose environmental and social responsibility information, despite the fact that for over six years the government has been pushing companies to report. A survey of the top 200 FTSE companies showed that 97 companies did not disclose any information on their social and environmental performance, that only 54 companies had produced stand-alone reports covering environmental and social issues and that only 16 companies said they would produce a report for the first time. Simon Propper, director of Environmental Context, said:
"It appears that companies resent attempts by Government to browbeat them into reporting. They see this as simply scratching the backs of the politicians and are calling the Government's bluff on threatened legislation. These companies don't yet recognise the many benefits, of taking the initiative and telling people what they are doing for the environment and society" (see
http://www.econtext.co.uk/debate_files/uk_comp_rej ect.html).

The most recent report published by Environmental Context shows a significant increase in corporate social responsibility (CSR) reporting on issues such as the environment, employee relations, respect for human rights and business ethics (Directions 2, Trends in Corporate Social Resposibility Reporting. 2001/2), Might this indicate a growing commitment to CSR and a growing recognition of the interests of stakeholders by companies? In recent years, much pressure has been exerted on companies to embrace CSR by the media, the public, by investors as well as shareholders themselves. It is hoped that we will, in the next few years, witness an increasing enthusiasm on the 
part of companies to make CSR more of a priority on their agendas. In the long run, this can only benefit the communities within which companies operate. For stakeholders and those who campaign for recognition of their interests, this may be the start of a new era.

\section{STAKEHOLDERS AND DUTY OF DIRECTORS TO PROMOTE SUCCESS}

Under the new framework, the primary goal of directors is to promote the success of the company in the collective best interests of the shareholders; however, directors must take into account, where circumstances so require, non-shareholder interests when considering, in good faith, what will best promote the success of the company. This does not mean however, that these interests have an independent value! For example, promoting employee welfare is not an end in itself, but as a means to promoting shareholder welfare. The keyword is the "success of the company in the collective best interests of the shareholders." The duty is thus phrased in a way which is "encompassing" only of stakeholder interests; these are to be considered in order that directors may reach a properly calculated view required in the core part of their duty. In other words, consideration of matters affecting stakeholders is subordinate to that of the directors' primary goal to promote the success of the company.

The duty also only requires directors to consider nonshareholder interests where it is "practicable in the circumstances for him to identify". One can imagine that time constraints on directors or the non availability of information might be construed as circumstances where it was not practicable for them to take into account nonshareholder interests. It is debatable whether the new duty will, in real terms, actually improve the lot of company stakeholders.

\section{OPERATING AND FINANCIAL REVIEW}

In his speech, Stephen Byers MP clearly stressed it was impracticable to impose a specific duty on directors to take stakeholder interests into account. The way to ensure that stakeholder interests were catered for, he said, was to focus on disclosure by companies of relevant issues. These could cover "relations with suppliers, customer complaints, employment policies, corporate governance, environmental, social and ethical policies where these are material to the business" and that "quality rather than quantity of information was important so that shareholders, customers and other stakeholders can make informed decisions."

The Review consulted widely on this issue of disclosure. It recommended that all companies of significant economic size (the majority of public companies and large private companies) should produce, as part of their annual report and accounts, an operating and financial review (OFR) which would provide key information about the company. The objective behind the OFR is to ensure, through transparency, responsible governance of companies with significant economic power (Final Report, 8.57). The OFR would be a qualitative, as well as financial, evaluation of performance, trends and intentions, prepared by the directors from their perspective as managers of the business and its purpose is to show, in the directors' own terms, what matters about the business as regards performance and direction (Final Report, 8.33: note the subjective content of the proposal).

"The requirement to produce an OFR would improve the quality, usefulness and relevance of information available to the markets and to everyone with an interest in the company... [it will] lead to improved understanding of business performance and prospects, as well as promoting accountability and encouraging responsiveness and high standards of business practice..." (Final Report, 3.34).

In making these recommendations, the Review was motivated partly by the fact that stakeholders such as employees, customers and the community have a legitimate interest in the activities of the company (especially those wielding significant economic power) and should therefore have access to relevant information about the company if need be (Final Report, 3.28-3.30). Under the OFR, directors will provide an explanation to shareholders and others as to how they have looked after their social responsibilities, employees, the environment and the community (see, e.g., David R, "The perfect time for a thorough rethink of company law", The Times, July 25, 2002, p.26). The Government welcomed these recommendations in its White Paper (see Vol 1, Pt 2, 4.28-4.41).

What kinds of information should the OFR contain? The White Paper, broadly following the recommendations of the Review, thought that in order to achieve the Review objective (see cl 73(3), Companies Bill) an OFR must contain at least the core elements:

(i) a statement of the company's business in the financial year to which the OFR relates,

(ii) a fair review of performance during that period and of the position of the company at the end of that period,

(iii) a fair projection of the prospects for the company's business and of events which will or may substantially affect that business (see cl 74, Companies Bill).

In addition, in forming an opinion as to whether the OFR achieved the Review objective, directors also have a duty to consider whether the inclusion of information about other matters is necessary. These include:

(1) the company's policies in relation to employment by the company,

(2) the company's policies on environmental issues relevant to the business,

(3) the company's policies on social and community issues 
relevant to the business and so on (see cl 75, Companies Bill).

For stakeholders, it is information in these categories which will be of particular significance and interest.

\section{STAKEHOLDERS AND THE OFR}

Given the new reporting obligations, one can expect useful information about the company's business in the OFR. Some of this information will concern stakeholders. Will preparing the OFR encourage directors to view the relationships between their companies and stakeholders from a fresh perspective? Will the reporting obligations under the new framework warrant stakeholders to expect that the company will take them more seriously? Lest we forget however, although directors have a duty to consider whether the inclusion of information about nonshareholder matters is necessary in order to achieve the Review objective, they do not have to include information on these matters if they did not think it was. It is therefore open to question whether in the end, there would be less, not more, information in a form that is useful in the OFR.

In embracing the OFR, the government may be seen as promoting CSR, helping to increase the number of companies to engage in CSR and deepening that engagement into something which influences all business activities instead of merely paying lip service to stakeholder interests. The criticism however, is that other than promoting disclosure of information by the company where relevant, it did not envisage strengthening the position of stakeholders in any other way. To be sure, the OFR will be informative. It will enable shareholders and others to make a proper judgement about the company, assess the strategies it has adopted and consider the potential for successfully achieving these strategies. But should stakeholders be able to challenge the OFR if it contained sparse or vague information, or no information at all? What if they felt their interests and concerns have not been given proper attention (this could easily happen, as what is important to one group of stakeholders may differ significantly from what matters to another, for example, environmental pressure groups $\mathrm{v}$ company employees)? Several other questions come to mind. What form should the OFR take? How should it be presented so that it is clear and understandable? Does inclusion of any information in the OFR amount to a commitment to implement any strategies or promises on the part of directors?

Both the Review and the White Paper have tackled these concerns to some extent (see also the recent Financial Services Authority Discussion Paper, "Review of the Listing regime", DP14, which envisages a review (at para. 4.24) of how the quality of information given to the market by companies can be improved). To help stimulate discussion of how the OFR should be implemented, Annex D of the White Paper provided a commentary on a preliminary draft of the OFR. (White Paper, Pt 2, 4.33-4.34, Final Report,
3.41, 8.49-8.52). Important issues such as form, content and audit were addressed. To help directors prepare their OFRs, the Standards Board will draw up detailed rules for their compilation and directors will be able to obtain guidance on how to assess whether an item is material to their company and should therefore be included in the OFR. The White Paper also stated that companies which failed to provide the right quantity as well as quality of information would risk adverse comparison and questions from their shareholders and others (White Paper, Vol 1, Pt 2, 4.33). Further, it envisaged that ultimately, and in the worst case scenario, directors may have to defend the process behind their reporting before the courts (White Paper, Vol 1, Pt 2, 4.33: see also the Final Report, 8.64-67, which elaborates on the power of the Reporting Review Panel to commence proceedings in court in respect of defective OFRs). Last but not least, the requirement that the OFR be audited by the company's auditors (see $\mathrm{cl} 81$, Companies Bill) should go some way (in theory!) toward ensuring that directors had thought long and hard about the nature of information included within it.

What is the next step? In embracing the OFR, the Government must ensure that directors are clear about its objectives; that to promote and improve transparency and accountability. Preparing the OFR must not be reduced to a cosmetic exercise with no real purpose. What use is the OFR if it was no more than just a legalistic document? Indeed both the Review and government were anxious to avoid "boiler plate" and "box ticking" type reporting on the part of companies (White Paper, Annex D, "Draft clauses on the OFR" at 16). The OFR must be a meaningful document and a yardstick against which directors can properly be judged by shareholders and the wider community. The Government must bear this important factor in mind in preparing directors for their task ahead.

Careful thought must also be given to how directors can best address non-shareholder matters in the OFR. In forming an opinion as to whether or not the OFR will achieve its review objective, directors have a duty to consider whether inclusion of information on these matters is necessary. This is a subjective judgement. Proper direction must thus be given to directors to ensure that they have considered these matters carefully and have made an appropriate judgement as to their relevance. Stakeholders are important constituents within the company in their own right. Their livelihood is affected by company activity. Directors need to be sensitive to their needs. The guidance (and training?) directors will receive in the preparation of their OFRs must equip them to be insightful, receptive and responsible to a constituent of the company which so much depends, on its livelihood, on how the company is run and managed.

\section{Lilian Miles}

School of Management, UMIST

With thanks to Giles Proctor, who as alwavs has provided very useful

comments on my work. 